IZA DP No. 4876

Intergenerational Earnings Mobility

and the Inheritance of Employers

Miles Corak

Patrizio Piraino

April 2010 


\title{
Intergenerational Earnings Mobility and the Inheritance of Employers
}

\author{
Miles Corak \\ University of Ottawa \\ and IZA \\ Patrizio Piraino \\ Statistics Canada
}

\author{
Discussion Paper No. 4876 \\ April 2010 \\ IZA \\ P.O. Box 7240 \\ 53072 Bonn \\ Germany \\ Phone: +49-228-3894-0 \\ Fax: +49-228-3894-180 \\ E-mail: iza@iza.org
}

Any opinions expressed here are those of the author(s) and not those of IZA. Research published in this series may include views on policy, but the institute itself takes no institutional policy positions.

The Institute for the Study of Labor (IZA) in Bonn is a local and virtual international research center and a place of communication between science, politics and business. IZA is an independent nonprofit organization supported by Deutsche Post Foundation. The center is associated with the University of Bonn and offers a stimulating research environment through its international network, workshops and conferences, data service, project support, research visits and doctoral program. IZA engages in (i) original and internationally competitive research in all fields of labor economics, (ii) development of policy concepts, and (iii) dissemination of research results and concepts to the interested public.

IZA Discussion Papers often represent preliminary work and are circulated to encourage discussion. Citation of such a paper should account for its provisional character. A revised version may be available directly from the author. 


\section{ABSTRACT \\ Intergenerational Earnings Mobility and the Inheritance of Employers*}

Our analysis of intergenerational earnings mobility modifies the Becker-Tomes model to incorporate the intergenerational transmission of employers, which is predicted to increase the intergenerational elasticity of earnings. About $6 \%$ of young Canadian men have the same main employer as their fathers but this is positively related to paternal earnings and rises discretely at the top of the distribution. We use a switching regression model and identify two regimes associated with the inheritance of employers that have different intergenerational earnings elasticities. The model also demonstrates that the inheritance of employers plays a role in understanding observed nonlinearities.

JEL Classification: J62, J64, J24

Keywords: intergenerational mobility, job search, networks

Corresponding author:

Miles Corak

Graduate School of Public and International Affairs

University of Ottawa

Desmarais Building, Room 11156

55 Laurier Avenue East

Ottawa, Ontario K1N 6N5

Canada

E-mail: corak@iza.org

\footnotetext{
* This is a revised version of a paper presented to the $30^{\text {th }}$ conference of the International Association for Research in Income and Wealth held in Portoroz Slovenia, August 2008, the "Intergenerational Mobility Conference", organized by the Centre for Longitudinal Studies and the Centre for the Economics of Education held at the London School of Economics in June 2008, London UK, and the conference on "Recent Developments in Research on Intergenerational Mobility" organized by the Scottish Institute for Research in Economics and held at the University of Edinburgh, Edinburgh UK also in June 2008. We thank the participants at these conferences for their feedback, and also Carlo Fiorio, Markus Jäntti, Sheng Guo, Sandra McNally and Krishna Pendakur for comments and suggestions. We acknowledge help during the early stages of constructing the data from Leonard Landry, Darren Lauzon, Sophie Lefebvre, and Debbie Tobalt, and the advice of Mikal Skuterud. We also thank Sheng Guo for the STATA code that formed the basis for our some of our empirical analysis. Corak acknowledges financial support from the Social Sciences and Humanities Research Council of Canada.
} 


\section{Intergenerational Earnings Mobility and the Inheritance of Employers}

A growing literature addressing the intergenerational transmission of earnings often forms the backdrop for policy discussions dealing with equality of opportunity. This literature is generally framed in the context of a linear regression to the mean model, and motivated theoretically by models of parental investments in the human capital of their children as in Becker and Tomes $(1986,1979)$ and Loury (1981). The major concern of the empirical research has been the challenge of correctly estimating the elasticity of earnings between parents and their children in the presence of measurement errors and life cycle biases. Solon $(1992,1989)$ and Zimmerman (1992) offer a starting point that has led to a large number of studies from a number of countries, surveyed by Björklund and Jäntti (2008), Corak (2006), and Solon (2002, 1999), with Böhlmark and Lindquist (2006), Grawe (2006), and Haider and Solon (2006) offering some of the most recent methodological developments.

Though this research is highly descriptive it has also led to a greater appreciation of causal processes. Attention to sibling and neighbourhood effects, as in for example Björklund et al. (2002), Björklund, Lindahl, Plug (2006), Oreopolous (2003), and the research summarized in Solon (1999), suggests that within family, as opposed to peer or neighbourhood, influences play the central role in determining the degree to which a child's life chances are tied to socio-economic background. As such these findings have links to the growing research on early childhood development, the formation of values and preferences, and their impact on readiness to learn and pro-social behavior that are important antecedents to educational attainment and ultimately labour market success. 
While this certainly relates to discussions of equality of opportunity there at the same time seems to be less emphasis on the structure of labour markets, the constraints or barriers embedded in them, and access to particular occupations or jobs, issues that traditionally also spoke to this policy concern. In fact, studies of the demand side of the labour market describe persistent differences in wages across firms and industries, as for example in Abowd, Kramarz, Margolis (1999) who examine wage differences between small and large firms or in Krueger and Summers (1988) who discuss inter-industry wage differences. These studies and an associated literature documenting within industry firm differences, as for example in Baldwin (1998), suggest that more productive and more highly-paid workers are concentrated in particular firms.

On the supply side it is also well-known that on the supply side families and friends play important roles in the job search process. Linda Datcher Loury (2006) suggests that up to $50 \%$ of jobs are found through family, friends or acquaintances, and also shows that the highest wages are paid to those who find jobs through "prior generation male" relatives who actually knew the potential employer or served as a reference. In this US study roughly $10 \%$ of men found jobs in this way.

If the demand side of the market is structured into high and low paying firms and if close family relatives play an important role in passing on jobs, then is it possible that the degree of intergenerational earnings mobility has something to do with not only human capital investment when children are young, but also with the firms with which they are employed as adults and the possibility that these firms are in some sense inherited? This is the question that motivates our research. Our analysis of intergenerational earnings mobility focuses on the role that parents may play in 
structuring the child's interface with the labour market, in the extreme influencing the degree to which employers are passed on across the generations. We examine this issue with a large administrative data set on a cohort of Canadian men containing information

for both fathers and sons on up to four employers per year, starting in the year the child was 15 years old and continuing to early adulthood.

We show that the intergenerational transmission of employers influences the intergenerational transmission of earnings in these data. In the first part of the paper, section 2, we draw on Mulligan $(1999,1997)$ to derive a number of insights from a reformulation of Becker and Tomes (1986). This analysis motivates our empirical model, and argues that parent-child earnings will be causally linked even in the context of perfect capital markets if employers are transmitted across the generations. Under a reasonable parameterization of the model the possibility of inheriting an employer raises the intergenerational earnings elasticity, also suggesting a nonlinearity that varies positively with paternal earnings. This analysis also motivates the use of a particular version of a switching regression model in our empirical analysis, which is pursued along with a description of the data in sections 3 to 5 of the paper. Section 6 concludes.

\section{Theoretical framework}

The general structure of models dealing with the intergenerational transmission of inequality involves a two period horizon in which parents use their income both for consumption and for investment in their children during the first period, while children work and consume as adults in the second period. Parents care both about own consumption in the first period and about some measure of their child's welfare-income or utility —in the second period. Their maximization problem involves allocating their 
endowment between current consumption and expenditures that will increase the earnings capacity, and hence future well-being, of their children. A simplified linear version of the earnings generating function for the child in adulthood, as presented in Becker and Tomes (1986), is offered as equation (1).

$$
\ln Y_{t}=\gamma_{t} H_{t}+\lambda E_{t}+l_{t}
$$

The earnings of an individual of generation $t$ are represented as $Y_{t}$, and reflect the human capital of the individual $H_{t}$, its valuation in the labour market $\gamma_{t}$, and market luck $l_{t}$. Human capital is assumed to be homogenous, and the total amount accumulated is proportional to the amount accumulated during childhood, reflecting the private expenditures of parents and the child's endowment, $E_{t}$. The latter, $E_{t}$, is thought of as ability, reflecting in most of this literature the cultural or genetic attributes of the family that are passed on to the child in a way not determined by parental control, and hence not responsive to incentives.

These endowments are assumed to be transmitted mechanically across generations according to a Markov process as given by, to use notation similar to Becker and Tomes (1986), equation (2).

$$
E_{t}=\alpha_{t}+h E_{t-1}+v_{t}
$$

Parents observe the endowments of their children, and make human capital investments that are subject to a diminishing marginal return. All parents are able to make the optimal investment notwithstanding their income or the ability level of their children if capital markets are assumed to be perfect. This assumption permits even low income parents of high ability children to make the optimal level of investment. In this way the human capital and hence earnings outcomes of children are separated from parental income, and 
the intergenerational transmission of inequality is determined by the degree to which ability is transmitted across the generations, as given by $h .{ }^{1}$ The fact that earnings regress to the mean according to the inheritability of endowments, and independently of parental earnings, is a key result in this strand of the literature.

Standard models of the transmission of earnings across the generations also predict that parent-child earnings will be correlated for reasons other than the intergenerational transmission of endowments. In Loury (1981) and Becker and Tomes (1986) it is recognized that some parents may not be able to invest the optimal amount of human capital in their children if there are borrowing constraints in financial markets that prevent the passing on of debt for repayment in the next generation from the increased earnings of the child. Parents must fund these investments by reducing their own consumption. This implies that the cost of funds are not the same across families, and also that they are increasing in the level of expenditures on the child's human capital as the reduction in consumption raises the shadow cost of additional expenditures. This is reflected in equation (3) by the positive influence of parental income in the educational attainment of children.

$$
H_{t}=\delta E_{t}+\theta \ln Y_{t-1}, \theta \geq 0
$$

Equation (3) refers to the behaviour of parents potentially constrained in the capital market. When $\theta>0$ capital markets are not perfect so that the child's level of human capital depends on parental income. The child's level of human capital is higher the more able the child, but also the higher the income of the parents. The incomes of some families will be high enough to make the optimal level of expenditures, but this will not

\footnotetext{
${ }^{1}$ As Mulligan (1997) makes clear this also assumes that parental preferences are homothetic and therefore that the degree and nature of intergenerational altruism implies linear expansion paths.
} 
be the case for other families. In the presence of borrowing constraints, earnings will persist across generations both because of inheritable endowments and because of suboptimal human capital investments. In other words, imperfect capital markets imply that child earnings will be related in a causal sense to parental earnings.

We augment this model by introducing the possibility of intergenerational transmission of employers. Following Mulligan (1999, 1997 pp. 55-7), we suggest that endowments have two dimensions: one that shifts the earnings function in a way that alters marginal returns and determines the efficient level of human capital; another that shifts it in an additive way and does not alter its slope. We suggest that the intergenerational transmission of employers is an endowment of this latter sort, reflecting the capacity of parents to influence the outcomes of the child's job search, and posit that this is positively related to parental earnings.

Different hypotheses for the existence of a positive relationship between parental earnings and the intergenerational transmission of employers can be found in the literature. For example, Shea (2000), among others, hypothesizes that fathers in unionized jobs are able to pass on employment with the same firm to their sons. Further, the union-non union wage premium implies that the children of these relatively higher earning fathers will also get a relatively higher wage offer from the firm. More generally, Atkinson, Maynard and Trinder (1983) note that this tendency will also depend upon the diversity of the local labour market and the hiring practices of firms. When local labour markets are dominated by a single employer, it is more likely that sons would be employed at the same firm as fathers even in a non-unionized setting. Further, this being a dominant or large employer in the labour market may also suggest a dominant position 
in product markets so that the firm's revenues may incorporate a rent that is shared with workers. This suggests that there is a wage premium to be had by employment in this firm, reflecting the type of arguments used to understand persistent inter-industry wage differences or the higher wages paid by large, perhaps more productive, firms.

The intergenerational transmission of employers could also be positively related to parental income because the degree of control parents have in the hiring policies of the firm may increase with income. In the extreme we can imagine parents being the owners of the firm and exerting preferential hiring of relatives. The literature on the succession of CEOs as in Pérez-González (2006) for the United States, and Bennedsen et al. (2007) for Denmark can be offered as an example of this possibility. ${ }^{2}$

Finally, we also note that the possibility of inheriting an employer will impact the earnings outcomes of children through their reservation wage. In a simple one-sided job search model with infinite horizons, no search costs, and exogenous job offer arrival rates the reservation wage is defined as $W^{R}=\mathrm{Z}+\frac{\omega}{\rho} \int_{W^{R}}^{\infty} \bar{F}(W) d W$ where $\mathrm{Z}$ is the value of nonwage income, $\omega$ is the job offer arrival rate, $\rho$ is the discount rate, and $\bar{F}(W)$ is the survivor function associated with the density of the job offer distribution. The possibility of inheriting an employer from a parent may increase job offer arrival rates from a particular firm as described in the previous paragraphs. But it might also impact upon the reservation wage. If this is the case, then the son's adult earnings may be influenced by

\footnotetext{
${ }^{2}$ The incidence of family based succession is high in the US data used by Pérez-González (2006), more than one-third of the slightly over 300 successions among publicly traded companies. As such this raises the possibility of nepotism as the mechanism for the intergenerational transmission of employers in a way that suggests a positive correlation with parental income.
} 
the possibility of inheriting his father's employer even if he does not ultimately work for this firm.

For a given job offer distribution the availability of a job in the father's firm, something the child knows with certainty, will lead to higher reservation wages in the same way that the availability of an independent source of income like unemployment insurance increases the reservation wages of the unemployed. In other words, we assume that $\delta Z_{t} / \delta Y_{t-1}>0$, higher earning parents are employed by higher- wage firms, and therefore any potential job offers these firms extend to the adult children are higher paying. Since $\delta W^{R} / \delta Z=1 /\left[1+\omega \bar{F}\left(W^{R}\right) / \rho\right]>0$, individuals with higher earning parents have higher reservation wages and therefore higher earnings. ${ }^{3}$ These earnings may well be obtained from firms other than the father's firm, but the probability of same firm employment will rise with the reservation wage of the child. This probability is $F\left(W^{R}\right)$, where $F()$ is the associated cumulative distribution function. Since $F\left(W^{R}\right)$ increases monotonically in value with $\mathrm{Z}$, the incidence of same firm employment is higher with higher Z. The probability of same firm employment approaches one at the highest possible values of $W^{R}$, and if it is the case that $Z$ increases monotonically with parent's earnings this implies a much higher chance of same firm employment among the sons of highest earning parents.

The possibility of being employed with the same firm that employed their parents is information available to children, and its impact on earnings is transmitted across the generations in a manner different than depicted in equation (2) for other endowments. In

\footnotetext{
${ }^{3}$ See Lancaster and Chesher (1983, pp. 1664-65). This result holds if $\delta F(W) / \delta Z=0$, that is if a marginal change in one firm's wage does not change the distribution over all firms.
} 
particular we suggest that the earnings generating function in equation (1) be modified as follows.

$$
\ln Y_{t}=\gamma_{t} H_{t}+\lambda E_{t}+\phi \ln Y_{t-1}+u_{t}
$$

In equation (4) earnings depend upon two types of endowments, ability $E_{t}$ and the earnings impact of parental job contacts represented as $\phi \ln Y_{t-1}$, where $\phi>0$ indicates that fathers with greater earnings are more able to pass on employment in higher paying firms. The point is that $Z$ influences the child's reservation wage, and this is what is implied by $\phi \ln Y_{t-1}$ replacing the last term in equation (1). This becomes the realization of a draw from a conditional rather than an unconditional distribution, and as a result $u_{t}$ represents the remaining component of earnings due to "luck".

These equations imply that $\ln Y_{t}=\left(\phi+\gamma_{t} \theta\right) \ln Y_{t-1}+\left(\lambda+\gamma_{t} \delta\right) E_{t}$. So for children of the same ability $E_{t}$, the child with higher earning parents will have higher expected earnings. This occurs for two reasons. First, higher income families are less severely constrained in the capital market. In the standard borrowing constraints model with one dimension of ability this effect is given by $\gamma_{t} \theta$. But this impact is accentuated by the presence of the second type of endowment so that the ultimate elasticity between parent and child earnings for children with equal $E_{t}$ is $\left(\phi+\gamma_{t} \theta\right)$. The presence of the intergenerational transmission of employers implies any given difference in income between parents of equally endowed children will lead to a higher difference in the longer run earnings of children because higher paid parents have a higher wage employer to pass on to their children.

As in the standard formulation this framework motivates and informs the use of a linear regression to the mean model of intergenerational mobility: $\ln Y_{t}=\alpha+\beta \ln Y_{t-1}+\varepsilon_{t}$, 
where $\beta$, the intergenerational earnings elasticity, is the parameter of interest in need of interpretation. Following the calculations in Solon (2004) we derive $\beta$ to be:

$$
\beta=\frac{\left(\phi+\gamma_{t} \theta\right)+h}{1+\left(\phi+\gamma_{t} \theta\right) h}
$$

This derivation clarifies that when both effects are in play, $\theta>0$ and $\phi>0$, the shape of the intergenerational earnings relationship is indeterminate. As such, nonlinearities cannot be used to test the predictions of the model without specifying how $\beta$ varies across the population as a result of the existence of both credit market distortions and the transmission of job contacts.

In the standard formulation $\phi=0$, and the discussion distinguishes a regime in which capital markets are perfect, with $\theta=0$ and therefore $\beta=h$, from a regime in which parents are not able to borrow against the future earnings of their children, with $\theta>0$, and $\beta=\frac{\theta \gamma_{t}+h}{1+\theta \gamma_{t} h}$, which is greater than $h$ when $\theta$ is less than one. In Becker and Tomes (1986) this latter regime is described to be the case for low income families, and as such a direct channel is opened between the earnings of parents and their children making the intergenerational tie in earnings stronger than it would have been had the optimal level of human capital expenditures been made. This model predicts a non-linear and concave relationship between parent and child earnings, or alternatively in the context of a linear specification the intergenerational earnings elasticity for the population as a whole is higher than it otherwise would be, and is driven by the higher elasticity at lower income 
levels. The two regimes, $\theta=0$ and $\theta>0$, are often distinguished by whether parents make financial transfers to their children or not, as in Mulligan (1999). ${ }^{4}$

Assume $\theta=0$, so that capital markets are perfect, and that $\phi>0$. Then $\beta=\frac{\phi+h}{1+\phi h}$, but in this case the higher intergenerational elasticity holds at higher earnings levels since those with higher earnings pass on another type of endowment to their children. In other words, this model also predicts a nonlinear relationship between the logarithm of parent and child earnings, but convex in nature with a higher elasticity at higher parental earnings because the children of these parents are both more likely to inherit an employer, and more likely to inherit a higher paying employer. In a similar manner this suggests that the population consists of a mixture of two types of individuals, and raises the issue of whether and how these regimes can be empirically identified.

For empirical purposes the impact of the intergenerational transmission of employers on earnings cannot be identified by separating the sample into two groups based upon the observation of whether or not the son works at the same employer as the father. The observed incidence of same employers across the generations understates the influence of employer inheritance because sons of high enough ability may have an optimal level of human capital investment that would imply higher earnings with other employers. Nonetheless, the opportunity to inherit the father's employer conditions their reservation wage and leads to higher earnings than their counterparts who are of equal ability and hold similar qualifications but who cannot inherit their father's employer, or

\footnotetext{
${ }^{4}$ Grawe (2004), Grawe and Mulligan (2002), Han and Mulligan (2001) point out that with heterogeneity in child abilities and parental altruism the relationship between parental income and being credit constrained is not straightforward and cannot be easily determined empirically. This in large part motivates Guo (2009) to frame this model in terms switching regressions with sample separation unknown or uncertain.
} 
whose father's are employed with a lower paying firm. ${ }^{5}$ As such information on whether a son actually works at the same employer as his father is not a perfect measure of whether or not the son had a possibility of inheriting an employer from his father, and this needs to be recognized in the empirical analysis. This is the challenge we address in the remainder of the paper.

3. Nature of the data and some preliminary results

Our analysis is based upon the Intergenerational Income Data (IID) we developed at Statistics Canada from administrative information on individual income tax returns that have been grouped into families. While we have information on a number of cohorts of young men, our focus is on the oldest group, those who are 33 years of age in the last year of observation. We observe their earnings in each year they file income taxes from the age 15 onward, and more importantly the earnings of their fathers since that time. For each year between 1978 and 1996 we also observe up to four employers that the sons and the fathers may have had. The appendix discusses the data in more detail.

Table 1 presents basic descriptive information. Father's earnings are averaged over the five year span in which the son was 15 to 19 years of age. To remain in the sample the father must have positive earnings in each of these five years. ${ }^{6}$ On average

\footnotetext{
${ }^{5}$ For that matter the observed incidence of intergenerational transmission of employers could also overstate the influence on a child's earnings in the sense that employers may be found independently of any parental role, particularly if labour markets are segmented geographically and there are only a few employers in the location for which job search occurs. If the allocation of employers were random there would be a possibility that some sons will work for the same employer as their sons, and this would have nothing to do with the job contacts and networks of the father that sons may rely on, with firm specific human-capital investments parents make in their children, or with nepotism.

${ }^{6}$ This is the preferred sample selection rule in Corak and Heisz (1999). They show that averaging over a five year horizon is long enough to correct for transitory earnings fluctuations. Mazumder (2005) suggests that almost twice as many years are necessary to correct for persistent transitory earnings fluctuations in the
} 
fathers are in their mid forties when we estimate their permanent earnings. Sons' earnings are averaged over a three year period, 1994 to 1996, conditional on reporting positive earnings in each of these three years. As such the sample of sons is relatively young. This is likely to lend a downward bias to estimates of the intergenerational earnings elasticity. This is one reason we focus most of our analysis on the oldest available cohort. This restriction also simplifies many of the calculations and makes the sample size - at just over 70,000-more manageable.

We work with a particular definition of whether or not a son is employed by the same firm as his father. It refers to the "main" employer of the father and the son, the employer accounting for the majority of earnings. We restrict this to mean the employer representing the majority of the father's earnings during the years the son was 15 to 19 years of age, and the employer accounting for the majority of the son's earnings when he was between ages 30 and 33. Just below six percent (5.9\%) of this cohort of young men have as their main employer in adulthood the same main employer their fathers had when they, the sons, were between the ages of 15 to 19 .

In fact, the lifetime incidence of the intergenerational transmission of employers is much higher: $41 \%$ of 33 year olds are or have been employed at some point since the age of 16 with an employer who also employed their father at any point in the past. ${ }^{7}$ In other words, many more sons have at some point been employed with at least one of their

US administrative data he uses. However, unlike these US data the earnings information from the IID is not top coded.

${ }^{7}$ We derive this figure by defining a vector of same-employer indicators that are set equal to one in year $t$ if any of the son's employers in year $t$ were the same as any of the father's employers over the period 1978 to $t-1$ inclusive. This definition of the intergenerational transmission of employers involves up to four different employers per year for both sons and fathers. At age 33 it represents the life time incidence of the intergenerational transmission of employers showing whether the son at any point since the age of 16 had the same employer as his father back to the year they were 15. See Corak and Piraino (2010) for a more detailed discussion and analysis. 
father's employers than actually have a career job with the employer that gave their fathers a career job. This lends credence to the previous discussion of the job search process by suggesting that the possibility of same firm employment across the generations is greater than what is observed by focusing on the career employer in adulthood.

The incidence of same main employer across the generations is positively associated with father's earnings. Figure 1 presents the proportion of sons in each percentile of the father's earnings distribution having the same main employer. For percentiles below about the $45^{\text {th }}$ the incidence is for the most part below the overall average of $5.9 \%$, while for percentiles above about the $55^{\text {th }}$ it is above. Its highest values are among the top 3 percentiles, displaying a distinct jump to about $10 \%$ at the $98^{\text {th }}$ and $99^{\text {th }}$ percentiles and then to almost $16 \%$ at the top percentile.

Table 2 offers the quartile transition matrix between father and son earnings, as well as the proportion of sons with the same main employer as the father in each cell. Many of the cells in the middle part of the transition matrix are not too different from 0.25 , but the probability that sons born to fathers in the bottom quartile become bottom quartile adults is over one-third as is the probability of sons born to top quartile fathers becoming top quartile adults. What distinguishes these two points is the fact that the proportion observed to have the same employer as their fathers is much higher among sons of top earning fathers. About $4 \%$ of sons of bottom quartile fathers have the same employer as their father regardless of whether they remain at the bottom of their earnings distribution or move to the top. In contrast, only $3 \%$ of the sons of top earning fathers who fall to the bottom quartile have the same employer as their father; while close to 
$12 \%$ of those who remain in the top quartile have the same employer as their father. A similar pattern holds for those born to fathers in the third quartile, and to a lesser degree the second quartile. For the most part it is also the case that the upward movement of one quartile from the father's original position is associated with a higher percentage of same firm employment than that associated with sons who remain in the same quartile as their fathers. Similarly downward mobility of one quartile is associated with a lower fraction of same firm employment than that associated with sons who remain in the same quartile.

\section{The Empirical Model}

Our objective is to estimate the intergenerational earnings elasticity by recognizing that the population of sons consists of a mixture of two groups, those who draw on parental job contacts and those who do not. The empirical strategy is to split the sample of families by the likelihood of having intergenerational contacts, and to assume separate linear models of earnings transmission for the two groups. Our theoretical discussion offers the logic behind this approach, namely that the group more likely to exploit parental networks should experience more intergenerational earnings persistence under the assumption of perfect capital markets. These families are identified by exploiting the information available in our dataset.

Consider again the standard intergenerational earnings relationship $\ln Y_{t}=\alpha+$ $\beta \ln Y_{t-1}+\varepsilon_{t}$, but expressed as two distinct regression regimes: the first applying to individuals without intergenerational job contacts (say $I=0$ ); the second to those with contacts (with $I=1$ ).

$$
\begin{array}{ll}
\ln Y_{t}^{0}=\alpha_{0}+\beta_{0} \ln Y_{t-1}^{0}+\varepsilon_{0} & \text { if } I=0 \\
\ln Y_{t}^{1}=\alpha_{1}+\beta_{1} \ln Y_{t-1}^{1}+\varepsilon_{1} & \text { if } I=1
\end{array}
$$


We can think of the system described by equations (6) and (7) as a switching regression model. Three types of switching regressions can be distinguished depending upon the information available for the indicator $I$. If $I$ is observed with certainty, the model is characterized with a known sample separation and the two equations can be estimated separately. If $I$ is unobserved, the switching regression model has unknown sample separation, with each observation having an unknown probability $p \equiv \operatorname{Pr}(I=1)$ of belonging to regime 1 , and probability $1-p$ of belonging to regime 0 . The econometric challenge, in this case, is to estimate the parameters $\beta_{1}$ and $\beta_{0}$ without knowing a priori which of the $n$ values of the dependent variable was generated by which regime (Quandt, 1972). When some information on $I$ is available but this information is only partial, the model is one of imperfect sample separation. In this case, the "true" regime is unobservable, but there exists a proxy measure, $Z$, which identifies the regimes with error.

We focus on this latter case in order to recognize the degree of uncertainty with which our indicator of intergenerational transmission of employers discriminates the sample observations across the true underlying regimes. In other words, we take into account the fact that the subsamples of individuals working and not working for a past employer of their father (respectively with $Z=1$ and $Z=0$ ), will in effect be made up of mixed groups, with observations from both regimes $(I=0$ and $I=1)$. This is the scenario studied in Lee and Porter (1984), who show that any misclassification will result in biased estimates of the $\beta$ coefficients if the sample separation is treated as known. 
We follow Lee and Porter (1984) as developed in Maddala (1986, pp.1646-8) and Guo (2009) to derive the likelihood function for the system of equations (6) and (7). Assuming that the error terms in the two regression regimes $\varepsilon_{1}$ and $\varepsilon_{0}$ are independently and normally distributed with mean zero and constant (though not necessarily equal) variances, we can express the probability density function for $Y_{t}$ in regime $I=0,1$ as

$$
f_{i}=\frac{1}{(2 \pi)^{1 / 2} \sigma_{i}} \exp \left[-\frac{1}{2 \sigma_{i}}\left(Y_{t}^{i}-\beta Y_{t-1}^{i}\right)^{2}\right] \quad \text { for } i=0,1
$$

from which the joint density of $Y_{t}$ and $Z$ can be derived

$$
f\left(Y_{t} \mid Z\right)=\left[f_{1} p_{1}+f_{0}\left(1-p_{1}\right)\right]^{Z}\left[f_{1}\left(1-p_{0}\right)+f_{0} p_{0}\right]^{1-Z}
$$

where $p_{1}=\operatorname{Pr}(I=1 \mid Z=1)$ and $p_{0}=\operatorname{Pr}(I=0 \mid Z=0)$. Thus, the distribution of $\ln Y_{t}$ is a mixture of two normal distributions, and is estimated by maximum likelihood under this assumption.

The identification of the parameters in the likelihood function is reached when $a$ priori information to distinguish between the two regimes is available (Lee and Porter 1984, Guo 2009). In our case, we assume that those who work for the same employer as their father are more likely to be in the intergenerational job contact regime. That is, we assume that $\operatorname{Pr}(I=1 \mid Z=1)>\operatorname{Pr}(I=1 \mid Z=0)$, and that $\operatorname{Pr}(I=0 \mid Z=0)>\operatorname{Pr}(I=0 \mid Z=1)$ which implies that $p_{1}+p_{0}>1 .^{8}$ In our application the functional form of $p_{1}$ and $p_{0}$ is parametrized as a probit function $\Phi\left(\gamma_{0}+\gamma_{1} Z\right)$.

5. Estimates of the intergenerational elasticity of earnings

\footnotetext{
${ }^{8}$ Lee and Porter (1984) and Guo (2009) offer the proof of identification.
} 
To fix ideas Table 3 offers the results from least squares estimation under the assumptions of no sample separation, and of exogenous and known sample separation. Least squares leads to an estimated intergenerational elasticity of 0.250 . This is at the upper end of the range reported in the empirical literature for Canada using these data as well as Instrumental Variables estimators from survey data. This reflects our decision to focus on just the 33 year olds, the oldest cohort available to us. ${ }^{9}$

When we assume that sample separation is exogenous and known the intergenerational elasticity for those with the same employer as their father is estimated to be just above 0.4 , higher than any results from a linear specification reported in the Canadian literature. Table 3 also reports similar results for two different samples: one using the observations from the bottom $95 \%$ of the father's earnings distribution, and another based upon the top five percentiles. We examine these samples separately because of the suggestion in Figure 1 that there is a distinct rise in the intergenerational transmission of employers at the very top of the distribution. This is also in line with the non-parametric results in Corak and Heisz (1999) that suggest a distinct non-linearity in the intergenerational earnings elasticity at the very top few percentiles of the father's earnings distribution. The results in panel 4 show that for the top 5\% of the father's earnings distribution the difference in the estimated elasticities across regimes is larger. ${ }^{10}$

We use the estimates reported in panel 2 of this table as starting values for the maximum likelihood estimation, the results of which are reported in Tables 4 and 5 for

\footnotetext{
${ }^{9}$ When a cohort of 30 to 33 year olds is used we obtain an intergenerational elasticity of 0.224 , which is more in line with other research (Corak and Heisz 1999, Fortin and Lefebvre 1997). Corak (2006) and d'Addio (2007) report that as such Canada is among the relatively more mobile countries for which comparable estimates are available, in particular an intergenerational elasticity of a little over 0.2 is about half as great than commonly reported for the United States.

${ }^{10}$ The differences between the two elasticities for each panel are respectively: $0.178(0.021), 0.222$ (0.026), $0.389(0.085)$, with the numbers in parentheses indicating the standard error.
} 
each of three samples, and for sample separation unknown and known imperfectly. These models use the same main employer indicator as the imperfect classifier of the regime. Table 4 offers the switching regression estimates for the intergenerational regression to the mean model when sample separation is unknown. The results show significant differences between regimes and across the father's earnings distribution. In the top two panels, regime 1 is associated with less intergenerational persistence of earnings, while the opposite is true when we focus on the top $5 \%$ of the father's earnings distribution (panel 3). Since sample separation is unknown, we cannot attempt a theoretical interpretation of these findings. That is, we cannot identify which regime corresponds to the 'job contacts regime' from the perspective of our augmented Becker-Tomes model. We can say, however, that the data are consistent with the hypothesis that the samples are partitioned in two distinct regression regimes, and we can estimate the probabilities associated to each of them. About 60 percent of observations are associated with regime 1 in panels 1 and 2, while for the top 5\% of father's earnings distribution (panel 3) the probability of belonging to regime 1 is estimated at 41 percent.

In Table 5, we use the indicator of same main employer as a proxy for regime classification. As explained, the identification of regimes rests on the assumption that sons working for a former employer of their father are more likely to be in the "job contacts regime." This proxy variable enters the likelihood expression in the probability function associated with each regime, $\Phi\left(\gamma_{0}+\gamma_{1} Z\right)$, so that the sign of the coefficient $\gamma_{1}$ on the same main employer dummy identifies the regression regime corresponding to the presence of job contacts. Since the only difference in the likelihood function between the unknown and uncertain sample separation models is in the functional specification of the 
probabilities associated with the regimes, we should not expect appreciably different estimates of the intergenerational coefficients in the two models. In fact, the results in Table 5 closely resemble those in Table 4 . The only important difference is that in Table 5 we are able to label regime 1 as the 'job contacts' regime because of its positive correlation with the intergenerational transmission of employers.

In order to interpret the two-regime switching regression results in Table 5, we must specify how $\beta$ varies in the population in light of our theoretical framework. The augmented Becker-Tomes model shows that in the context of imperfect capital markets the intergenerational earnings elasticity will be affected by both credit market distortions and parental job contacts. The results in Table 5 provide evidence of the existence of multiple regimes across the father's earnings distribution, possibly as a result of the interaction between these two effects. Assuming that credit constraints are not binding for fathers in the top five percent of the distribution, the switching regression model in panel 3 cleanly distinguishes the two theoretical regimes with respect to parental job contacts. That is, the intergenerational transmission of employers increases the earnings elasticity as predicted by theory when credit markets are perfect. When credit constraints are binding, the possibility to draw on parental employer's network decreases the probability of being constrained. Since earnings persistence across generations is predicted to be higher among credit constrained families, the results in panels 1 and 2 could simply reflect the negative correlation between same firm employment and the susceptibility of being credit constrained.

We replicated Table 5 in two alternative ways. We used the presence of paternal self-employment as well as a broader measure of same firm employment—ever having 
been employed at the same employer as the father since the age of 16 - as the proxy

variables. These possibilities are drawn from the findngs in Corak and Piraino (2010) that having a self-employed father is associated with a much higher chance of same-firm employment across the generations, and that there is a significant degree of intergenerational transmission of employers when the entire available life cycle of the sons is examined. The results, which are not shown but available upon request, are essentially the same as those presented in Table 5, and confirm that all these proxies are acting to identify the regime.

\section{Conclusion}

In the standard model of intergenerational earnings mobility with perfect capital markets all adult children with the same human capital have the same endowment along the dimension that determines the optimal level of human capital investment. This implies that they all have the same anticipated earnings, which are unrelated in a causal sense to parental income. With earnings determined by two types of endowments this does not hold. In particular, we consider a model in which parental job contacts or firm-specific investments imply that some children will be employed with the same firm as their parents, and suggest that this is another endowment that directly influences the child's earnings function. This type of endowment opens a channel for parental earnings to directly influence child outcomes, similar in kind to the role of imperfect capital markets in the traditional formulation, but different in the sense that the resulting higher intergenerational elasticity occurs at the upper — not the lower-end of the parent's earnings distribution. This result follows from an assumption that the value of the 
intergenerational transmission of employers to the earnings of children is positively related to parental earnings.

This perspective suggests that the population is a mixture of two groups, those with the possibility of inheriting an employer from their fathers, and those without. As such the appropriate empirical strategy is to estimate the regression to the mean model in a switching regression framework. We use a large administrative based data set on a cohort of young Canadian men to estimate these models with sample separation unknown, and known imperfectly.

We document the fact that close to $6 \%$ of these young adults obtain the majority of their earnings from an employer who was also the main employer of their fathers some 15 to 20 years earlier, when they were young teenagers. Our empirical analysis recognizes that some sons who are never observed to have been employed at a firm that once employed their fathers may still have their reservation wages influenced by the possibility that they could have such employment. Others who are observed to have had such employment could have found the employer on their own without relying on information or contacts from their parents. As such we recognize that this is an imperfect indicator of regime type. Our maximum likelihood estimates account for this, and yield much higher estimates of the intergenerational earnings elasticity for those at the upper end tail of the father's earnings distribution who have the possibility of working in the same firm as their fathers. The preservation of intergenerational earnings status across the generations among the very rich is underpinned by the capacity of the sons to inherit their father's employer. 
Our research suggests that as the intergenerational earnings literature continues to address issues of causality it should also recognize that parents might invest in the success of their children throughout the course of their life cycle, not just in the early years. The structure of labour markets and the way in which young adults make the transition to their career job may also be an important part of the intergenerational dynamic determining their long-run attainments, an aspect that may be just as closely tied to issues of equality of opportunity. 
Appendix on the construction of the data

These data are also used in Corak and Piraino (2010) to discuss the intergenerational transmission of employers, and this appendix draws from their exposition. Canadians file their income tax returns (so-called T1 Forms) on an individual basis, and Statistics Canada has grouped these into families using a variety of matching strategies that are described in Harris and Lucaciu (1994). The resulting T1 Family File (T1FF) is the basic building block for the creation of the IID, an intergenerational linked set of T1 Forms for a series of cohorts of young men and women, and their mothers and fathers. This represents not quite four million individuals and their parents, and in particular 1.9 million men who are the starting point for our research. We focus on the male cohort born between 1963 and 1966, and in fact for the most part the oldest subset born in 1963. These individuals are linked to their fathers - not necessarily their biological fathers - if they filed an income tax return between 1982 and 1986 while still living at home. This is required to ensure that a parent-child match is made, and also that the child has an observed Social Insurance Number (SIN), a unique individual identifier that can then be used to link all subsequent T1 Forms which contain information on earnings. These T1 Forms are available for all years between 1978 and 1996.

The algorithm used to create the data leads to an under-representation of children from lower income backgrounds, and from the major metropolitan areas: Montreal, Toronto, and Vancouver. This reflects the fact that children who leave home early or who otherwise are not engaged in the labour market while at home are less likely to be linked to a parent. It also reflects the fact that new immigrants and their children will be underrepresented in the data, the majority having a tendency to settle in the three major cities of the country. Weights based upon Census data have been created to account for this, and our analysis uses them throughout even though they make no difference to the results.

The sample sizes associated with the creation of our analytical files are detailed in Appendix Table A1, which makes clear that they are large-measured in the tens and hundreds of thousands - given that the data potentially represent the universe of individuals in these age groups.

Versions of these data have been used by Blanden (2005), Corak (2001), Corak, Gustafsson, and Österberg (2004), Corak and Heisz (1999), Grawe (2006, 2004), Oreopoulos (2003) and Oreopoulos, Page and Huff Stevens (2008) to study a host of issues dealing with intergenerational mobility. Our application is unique in that we further develop the data by adding information on the specific firms employing parents and children throughout the period they are observed. We do this by relying upon a longitudinally consistent catalogue of all enterprises in the country, linked to individuals through the earnings remittance forms issued to employees (the T4) and used to support their income tax returns. This database of firms is referred to as the Longitudinal Employment Analysis Program (LEAP). See Statistics Canada $(1992,1988)$ for a description of its construction and use. Each T4 has a payroll deduction account number unique to a firm, and the LEAP serves to aggregate the possibly many account numbers per firm into a single longitudinally consistent identifier. For each individual (fathers and sons), and for each year from 1978 to 1996 we obtain unique firm identifiers for up to four employers. Very few individuals ever have more than four different employers in 
any given year. Using the individual's earnings from each employer we designate for a given year the firm accounting for the majority of total earnings as the "main" employer in that year, or sometimes over a five year horizon according to our analytical needs.

The LEAP offers an accurate representation of the private sector but our analysis of the intergenerational transfer of employers is hampered by the fact that it does not distinguish separate employers in the public sector. This refers to federal and provincial public services but not to municipal governments. For anything finer than a two digit industry analysis this will overstate the degree to which employers or industries are passed across the generations. In order to recognize this, we consider father-son matches in employment in the public service as missing information on same firm employment. Accordingly we note that the analysis offers conservative estimates of the degree of intergenerational job contacts.

\section{Appendix Table A1}

Sample sizes associated with the creation of the analytical files from the Intergenerational Income Data

\section{Sample size $\quad$ Weighted sample size}

Entire sample, all male cohorts

1963 to 1966 male cohorts

Fathers with positive earnings in each of five years

when sons were 15 to 19 years of age

Sons with positive earnings in each of three years between 1994 and 1996

Bottom percentile fathers and bottom percentile sons deleted

Fathers born between 1908 and 1952

Only 1963 cohort, those 33 years of age in 1996
$1,890,923$

$2,474,667$

653,959

886,099

340,199

417,510

240,478

294,706

236,490

288,964

236,210

288,607

71,125
84,343 


\section{References}

Abowd, John M., Francis Kramarz, and David N. Margolis (1999), "High-Wage Workers and High-Wage Firms.” Econometrica. Vol. 67, pp. 251-333.

Atkinson, A. B., A. K. Maynard, and C. G. Trinder (1983). Parents and Children: Incomes in Two Generations. London: Heinemann Educational Books.

Baldwin, John R. (1998). The Dynamics of Industrial Competition. Cambridge: Cambridge University Press.

Becker, Gary S. and Nigel Tomes (1986). "Human Capital and the Rise and Fall of Families." Journal of Labor Economics. Vol. 4, pp. S1-39.

Becker, Gary S. and Nigel Tomes (1979). “An Equilibrium Theory of the Distribution of Income and Intergenerational Mobility." Journal of Political Economy. Vol. 87, pp. 1153-89.

Bennedsen, Morton, Kasper Meisner Nielsen, Francisco Pérez-González, and Daniel Wolfenzon (2007). "Inside the Family Firm: The Role of Families in Succession Decisions and Performance.” Quarterly Journal of Economics. Vol. 122, pp. 64791.

Björklund, Anders and Markus Jäntti (2008). "Intergenerational income mobility and the role of family background.” In Wiemer Salverda, Brian Nolan, and Tim Smeeding (editors). Handbook of Economic Inequality. Oxford: Oxford University Press, forthcoming.

Björklund, Anders, Mikael Lindahl, and Erik Plug (2006). “The Origins of Intergenerational Associations: Lessons from Swedish Adoption Data." Quarterly Journal of Economics. Vol. 121, pp. 999-1028. 
Björklund, Anders, Tor Eriksson, Markus Jäntti, Oddbjørn Raaum and Eva Österbacka (2002). "Brother Correlations in Earnings in Denmark, Finland, Norway and Sweden compared to the United States." Journal of Population Economics. Vol. 15, pp. $757-772$.

Blanden, Jo (2005). "Love and Money: Intergenerational Mobility and Marital Matching in Canada." Ottawa: Statistics Canada Research Paper No. 272.

Böhlmark, Anders and Matthew J. Lindquist (2006). "Life-Cycle Variations in the Association between Current and Lifetime Income: Replication and Extension for Sweden." Journal of Labor Economics. Vol. 24, pp. 879-96.

Corak, Miles (2006). "Do poor children become poor adults? Lessons from a cross country comparison of generational earnings mobility.” In John Creedy and Guyonne Kalb (editors). Research on Economic Inequality, Vol. 13. Amsterdam: Elsevier.

Corak, Miles (2001). "Death and Divorce: The Long-Term Consequences of Parental Loss on Adolescents.” Journal of Labor Economics. Vol. 19, pp. 682-715. Corak, Miles, Björn Gustafsson, and Torun Österberg (2004). "Intergenerational Influences on the Receipt of Unemployment Insurance in Canada and Sweden.” In Miles Corak, editor. Generational Income Mobility in North America and Europe. Cambridge: Cambridge University Press.

Corak, Miles and Andrew Heisz (1999). "The Intergenerational Earnings and Income Mobility of Canadian Men: Evidence from Longitudinal Income Tax Data.” Journal of Human Resources. Vol. 34, pp. 504-33. 
Corak, Miles and Patrizio Piraino (2010). "The intergenerational transmission of employers.” IZA Discussion paper number 4819.

D’Addio, Anna Cristina (2007). “Intergenerational Transmission of Disadvantage: Mobility or Immobility across Generations? A Review of the Evidence for OECD Countries." OECD Social and Employment Working Papers No. 52.

Datcher Loury, Linda (2006). "Some contacts are more equal than others: Informal networks, job tenure, and wages." Journal of Labor Economics. Vol. 24, pp. 299318.

Grawe, Nathan D. (2006). "The Extent of Lifecycle Bias in Estimates of Intergenerational Earnings Persistence.” Labour Economics. Vol. 13, pp. 551-570.

Grawe, Nathan D. (2004). "Reconsidering the Use of Nonlinearities in Intergenerational Earnings Mobility as a Test for Credit Constraints." Journal of Human Resources. Vol. 39, pp. 813-827.

Grawe, Nathan D. and Casey B. Mulligan (2002). "Economic Interpretations of Intergenerational Correlations." Journal of Economic Perspectives. Vol. 16, pp. 4558.

Guo, Sheng (2009). "Rich Dad, Rich Kid? Switching Regression Estimates of Intergenerational Mobility of Consumption.” Working Paper. Florida International University.

Haider, Steven J. and Gary Solon (2006). "Life-Cycle Variation in the Association between Current and Lifetime Earnings." American Economic Review. Vol. 96, pp. 1308-20. 
Han, Song and Casey B. Mulligan (2001). "Human Capital, Heterogeneity and Estimated Degrees of Intergenerational Mobility.” Economic Journal. Vol. 111, pp. 207-43. Harris, Shelly and Daniela Lucaciu (1994). "An overview of the T1FF Creation.” LAD Reports. Reference Number 94-24-01 v1.2. Ottawa: Statistics Canada, Small Areas and Administrative Data Division.

Krueger, Alan B. and Lawrence H. Summers (1988). "Efficiency Wages and the InterIndustry Wage Structure.” Econometrica. Vol. 56, pp. 259-93.

Lancaster, Tony and Andrew Chesher (1983). “An Econometric Analysis of Reservation Wages." Econometrica. Vol. 51, pp. 1661-1676.

Lee, L. F. and R.H. Porter (1984). "Switching Regression Models with Imperfect Sample Separation Information: With an Application on Cartel Stability." Econometrica. Vol. 52, pp. 391-418.

Loury, Glenn C. (1981). "Generational Transfers and the Distribution of Earnings." Econometrica. Vol. 49, pp.843-67.

Maddala, G. S. (1986). “Disequilibrium, Self-Selection, and Switching Models.” In Z. Griliches and M. D. Intrilligator (editors). Handbook of Econometrics, Volume III. North Holland, Elsevier Science Publishers.

Maddala, G. S. (1983). Limited-Dependent and Qualitative Variables in Econometrics. Cambridge: Cambridge University Press.

Mulligan, Casey B. (1999). "Galton versus the Human Capital Approach to Inheritance.” Journal of Political Economy. Vol. 107, No. 6, Part 2: Symposium on the Economic Analysis of Social Behavior in Honor of Gary S. Becker, pp. S184-S224. 
Mulligan, Casey B. (1997). Parental Priorities and Economic Inequality. Chicago: University of Chicago Press.

Mazumder, Bhashkar (2005). "Fortunate Sons: New Estiamtes of Intergenerational Mobility in the United States Using Social Security Earnings Data." Review of Economics and Statistics. Vol. 87, pp. 235-55.

Oreopoulos, Philip (2003). “The Long-Run Consequences of Growing Up in a Poor Neighbourhood." Quarterly Journal of Economics. Vol. 118, pp. 1533-75.

Oreopoulos, Philip, Marianne Page, and Ann Huff Stevens (2008). "The Intergenerational Effects of Worker Displacement." Journal of Labor Economics. Vol. 26, pp.455-84. Pérez-González, Francisco (2006). "Inherited Control and Firm Performance." American Economic Review. Vol. 96, pp. 1559-88.

Rosenzweig, M. R. and K. I. Wolpin (1985). "Specific experience, household structure and intergenerational transfers: farm family land and labor arrangements in developing countries." Quarterly Journal of Economics. Vol. 100, pp. 961-87. Shea, John (2000). “Does Parents’ Money Matter?” Journal of Public Economics. Vol. 177, pp. 155-84.

Solon, Gary (2004). “A model of intergenerational mobility variation over time and place." In Miles Corak, editor. Generational Income Mobility in North America and Europe. Cambridge: Cambridge University Press.

Solon, Gary (2002). "Cross-Country Differences in Intergenerational Earnings Mobility.” Journal of Economic Perspectives. Vol. 16, 59-66. 
Solon, Gary (1999). “Intergenerational Mobility in the Labor Market.” In Orley C. Ashenfelter and David Card (editors). Handbook of Labor Economics, Volume 3 A. Amsterdam: Elsevier Science.

Solon, Gary (1992). "Intergenerational Income Mobility in the United States." American Economic Review. Vol. 82, 393-408.

Solon, Gary (1989). "Biases in the Estimation of Intergenerational Earnings Correlations." Review of Economics and Statistics. Vol. 71, pp. $172-74$.

Statistics Canada (1992). Worker Turnover in the Canadian Economy: Separations and Hirings, 1978-1989. Ottawa: Statistics Canada, Catalogue Number 71-539.

Statistics Canada (1988). Developing a Longitudinal Database on Businesses in the Canadian Economy. Ottawa: Statistics Canada, Catalogue Number 18-501.

Zimmerman, David J. (1992). "Regression Toward Mediocrity in Economic Structure." American Economic Review. Vol. 82, pp. 409-29. 


\section{Figure 1}

Proportion of sons with the same main employer as their father for each percentile of the father's earning distribution: father's main employer when son was 15 to 19 years compared to sons main employer between 30 and 33 years of age

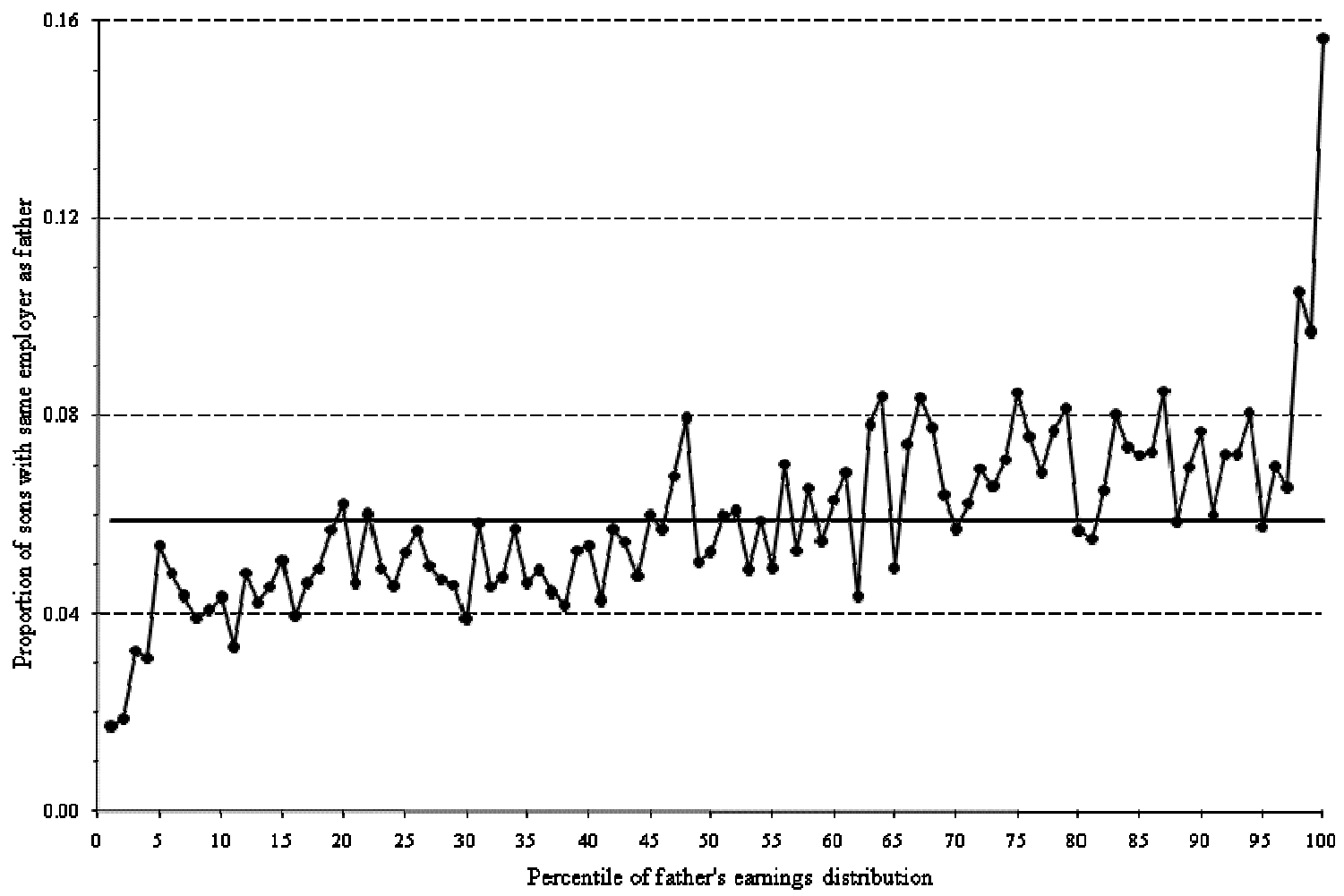

Note: The horizontal line is drawn at 0.059 , the incidence of same firm employment for the entire sample. Calculations are based on weighted observations of 71,215 sons who are 33 years of age. Father's earnings percentiles are calculated using a five-year average of earnings during the period sons were 15 to 19 years of age.

Source: Calcuations by authors using Statistics Canada administrative data as described in the text and the appendix. 
Table 1

Descriptive statistics for fathers and sons linked intergenerational

\begin{tabular}{|c|c|c|c|c|c|c|c|}
\hline & \multirow{2}{*}{$\begin{array}{c}\text { Number } \\
\text { of } \\
\text { observations }\end{array}$} & \multicolumn{2}{|c|}{ Average Age } & \multicolumn{2}{|c|}{ Average Earnings } & \multicolumn{2}{|c|}{$\begin{array}{c}\text { Number of unique } \\
\text { employers }\end{array}$} \\
\hline & & $\begin{array}{l}\text { Fathers } \\
(1980)\end{array}$ & $\begin{array}{c}\text { Sons } \\
(1996)\end{array}$ & Fathers & Sons & Fathers & Sons \\
\hline 1 Entire sample & 71,215 & $\begin{array}{c}47.4 \\
(6.14)\end{array}$ & 33 & $\begin{array}{c}43,524 \\
(27,085)\end{array}$ & $\begin{array}{c}36,129 \\
(22,953)\end{array}$ & 23,963 & 31,674 \\
\hline $\begin{array}{l}\text { 2. } 95^{\text {th }} \text { percentile and } \\
\text { below of father's } \\
\text { earnings distribution }\end{array}$ & 67,499 & $\begin{array}{c}47.3 \\
(6.18)\end{array}$ & 33 & $\begin{array}{c}39,724 \\
(15,377)\end{array}$ & $\begin{array}{c}35,434 \\
(20,904)\end{array}$ & 23,070 & 30,378 \\
\hline $\begin{array}{l}3.96^{\text {th }} \text { percentile and } \\
\text { above of } \\
\text { father's earnings } \\
\text { distribution }\end{array}$ & 3,716 & $\begin{array}{c}47.6 \\
(5.22)\end{array}$ & 33 & $\begin{array}{l}115,735 \\
(68,499)\end{array}$ & $\begin{array}{c}49,347 \\
(45,281)\end{array}$ & 2,018 & 2,643 \\
\hline
\end{tabular}

Note: Panel 1 refers to all inter-generationally linked sons born in 1963, and who are hence 33 years of age in 1996. Fathers' earnings are averaged over the five years the son was 15 to 19 years of age, and sons' earnings are averaged between 1994 and 1996. All monetary figures are expressed as constant 1992 dollars. The cut-off dollar value of the $95^{\text {th }}$ percentile of the father's earnings distribution is equal to $\$ 79,910$. The number of unique employers refers only to the main employer, the employer that paid the largest proportion of total earnings during the above periods. Figures in parentheses are standard deviations. 
Table 2

Quartile earnings transition matrix with proportions of intergenerational transmission of employers within each cell

A. Father-son earnings quartile transition matrix

Sons

\begin{tabular}{|c|c|c|c|c|}
\hline Fathers & Bottom & $2^{\text {nd }}$ & $3^{\text {rd }}$ & Top \\
\hline Bottom & 0.351 & 0.282 & 0.207 & 0.161 \\
\hline $2^{\text {nd }}$ & 0.267 & 0.277 & 0.254 & 0.202 \\
\hline $3^{\text {rd }}$ & 0.215 & 0.238 & 0.277 & 0.271 \\
\hline Top & 0.168 & 0.203 & 0.262 & 0.367 \\
\hline
\end{tabular}

B. Proportion of sons with the same main employer as father within each cell of the earnings quartile

Sons

\begin{tabular}{r|cccc}
\multicolumn{2}{r|}{ Fathers } & Bottom & $2^{\text {nd }}$ & $3^{\text {rd }}$ \\
\hline Bottom & 0.041 & 0.048 & 0.038 & 0.042 \\
$2^{\text {nd }}$ & 0.027 & 0.059 & 0.067 & 0.061 \\
$3^{\text {rd }}$ & 0.022 & 0.046 & 0.083 & 0.101 \\
Top & 0.029 & 0.044 & 0.079 & 0.116
\end{tabular}


Table 3

Least squares estimates of a linear regression to the mean model of intergenerational earnings mobility: no sample separation, and sample separation exogenous and known

\begin{tabular}{|c|c|c|c|c|}
\hline & & \multicolumn{3}{|c|}{ Least squares estimates } \\
\hline & & Constant & Coefficient & Sample Size \\
\hline 1. & No sample separation & 7.50 & 0.250 & 71,215 \\
\hline \multicolumn{5}{|c|}{ 2. Sample separation exogenous and known } \\
\hline & No same main employer in adulthood & 7.60 & 0.235 & 66,949 \\
\hline & Had same main employer in adulthood & 6.87 & 0.413 & 4,266 \\
\hline \multirow[t]{5}{*}{3.} & Bottom $95 \%$ of father's earnings distribution & & & \\
\hline & No sample separation & 7.48 & 0.249 & 67,499 \\
\hline & Sample separation exogenous and known & & & \\
\hline & No same main employer in adulthood & 7.57 & 0.236 & 63,599 \\
\hline & Had same main employer in adulthood & 6.16 & 0.458 & 3,900 \\
\hline \multirow[t]{5}{*}{4.} & Top 5\% of father's earnings distribution & & & \\
\hline & No sample separation & 9.17 & 0.248 & 3,716 \\
\hline & Sample separation exogenous and known & & & \\
\hline & No same main employer in adulthood & 9.82 & 0.144 & 3,350 \\
\hline & Had same main employer in adulthood & 10.66 & 0.533 & 366 \\
\hline
\end{tabular}

Note: Table entries are least squares coefficient estimates based upon a linear regression to the mean model with the natural logarithm of son's earnings averaged over three years (1994 to 1996) as the dependent variable, and the natural logarithm of the five year average of father's earnings during the years the son was 15 to 19 years of age. The model also controls for the age and age squared of the father. All sons are 33 years of age in 1996. All estimates are statistically significant at the $1 \%$ level. 
Table 4

Maximum likelihood estimates of a switching regression to the mean model of intergenerational earnings mobility: sample separation unknown

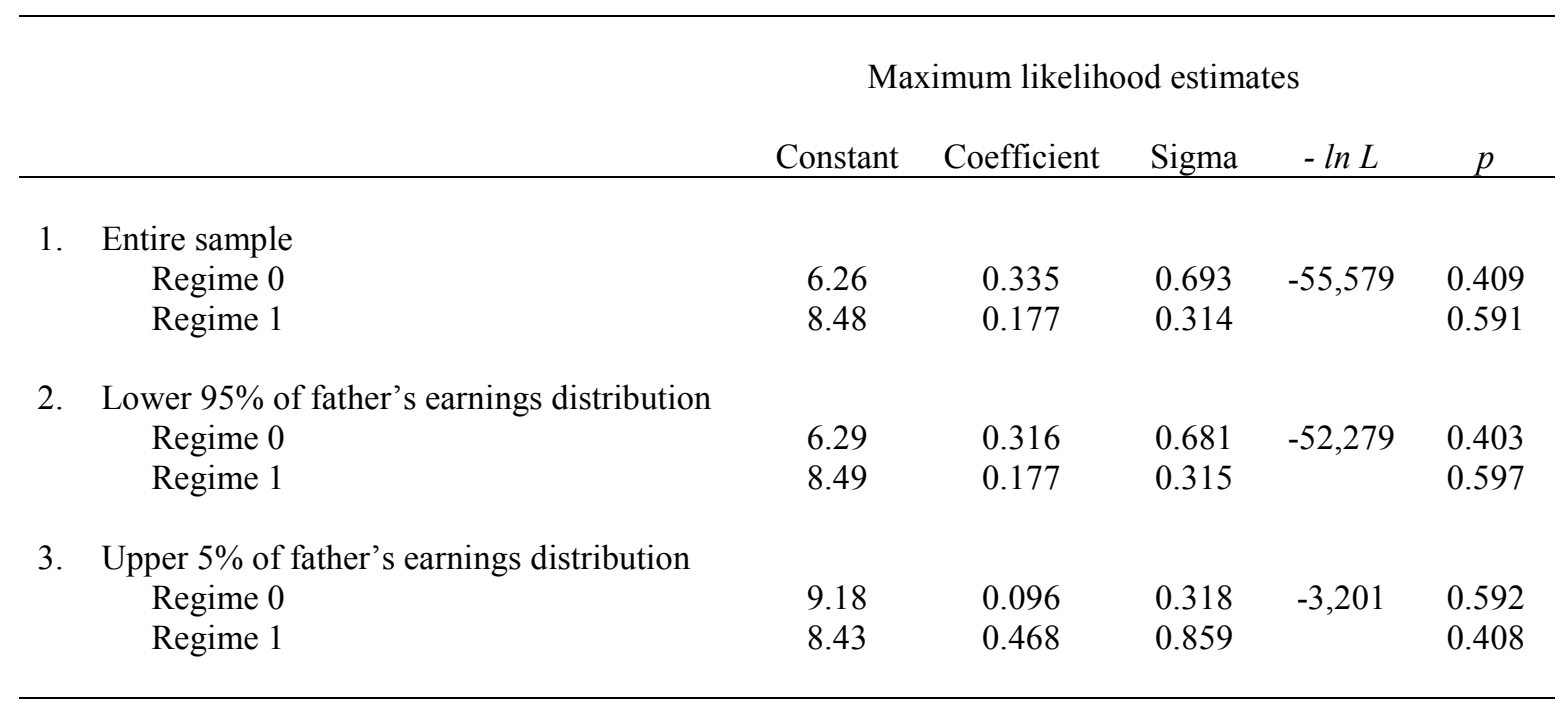

Note: Table entries are maximum likelihood estimates using a Berndt-Hall-Hall-Hausman algorithm, with starting values given by least squares as presented in Table 3, panel 2. Standard errors are estimated using the Outer Product of the Gradient. Convergence was attained within 20 iterations. All coefficients are significant at the 5\% level. The model also controls for the age and age squared of the father. All sons are 33 years of age in 1996. Sample sizes for panels labelled 1,2, and 3 are respectively: 71,215, 67,499, and 3,716.

The column labelled $p$ refers to the probability associated with each regime, parameterized as $\Phi\left(\gamma_{0}\right)$. 
Table 5

Maximum likelihood estimates of a switching regression to the mean model of intergenerational earnings mobility: imperfect sample separation

\author{
Maximum likelihood estimates
}

Constant Coefficient Sigma $-\ln L \quad p$

\begin{tabular}{rlrrrr} 
1. Entire sample & 6.45 & 0.314 & 0.691 & $-55,378$ & 0.409 \\
Regime 0 & 8.40 & 0.187 & 0.314 & & 0.591 \\
Regime 1 & \multicolumn{5}{c}{$\gamma_{1}=0.7430$}
\end{tabular}

2. Lower $95 \%$ of father's earnings distribution

\begin{tabular}{|c|c|c|c|c|c|}
\hline \multirow{3}{*}{$\begin{array}{l}\text { Regime } 0 \\
\text { Regime } 1\end{array}$} & 6.47 & 0.297 & 0.680 & \multirow[t]{2}{*}{$-52,058$} & 0.405 \\
\hline & 8.44 & 0.184 & 0.315 & & 0.595 \\
\hline & \multicolumn{4}{|c|}{$\gamma_{1}=0.8129$} & \\
\hline \multicolumn{6}{|c|}{ oper $5 \%$ of father's earnings distribution } \\
\hline Regime 0 & 9.36 & 0.078 & 0.318 & $-3,200$ & 0.591 \\
\hline \multirow[t]{2}{*}{ Regime 1} & 8.28 & 0.485 & 0.860 & & 0.409 \\
\hline & \multicolumn{5}{|c|}{$\gamma_{1}=0.2117$} \\
\hline
\end{tabular}

Note: Table entries are maximum likelihood estimates using a Berndt-Hall-Hall-Hausman algorithm, with starting values given by least squares as presented in Table 3. Standard errors are estimated using the Outer Product of the Gradient. Convergence was attained within 20 iterations. All coefficients are significant at the 5\% level. The model also controls for the age and age squared of the father. All sons are 33 years of age in 1996. Sample sizes for panels labelled 1,2, and 3 are respectively: 71,215, 67,499, and 3,716.

The column labelled $p$ refers to the probability associated with each regime, calculated as $\Phi\left(\gamma_{0}\right) * \operatorname{Pr}(Z=0)+\Phi\left(\gamma_{0}+\gamma_{1} Z\right) * \operatorname{Pr}(Z=1)$. 